УДК:343.141; 343.140 .02

DOI https: / / doi.org/10.32837/yuv.v0i4.988

\author{
Г. Устінова-Бойченко, \\ кандидат юридичних наук, доцент, \\ завідувач кафедри кримінально-правових дисциплін \\ Криворізького факультету \\ Національного університету «Одеська юридична академія»
}

\begin{abstract}
T. Черниш,
викладач кафедри конституційного, міжнародного та приватного права

Криворізького факультету

Національного університету «Одеська юридична академія»
\end{abstract}

Ю. Чабаненко,

асистент кафедри кримінально-правових дисциплін

Криворізького факультету

Національного університету «Одеська юридична академія»

\title{
МІСЦЕ ПРЕЮДИЦІАЛЬНИХ ФАКТІВ У ПРОЦЕСІ КРИМІНАЛЬНО-ПРОЦЕСУАЛЬНОГО ДОКАЗУВАННЯ
}

Процес доказування, який включає такі етапи, як збирання, дослідження та оцінка доказів, є головним компонентом прийняття законного та справедливого судового рішення у будьякому виді судочинства. Обов'язок доказування покладається на учасників процесу, а оцінка доказів здійснюється судом відповідно до норм матеріального та процесуального права. Зафіксовані у судовому рішення факти та обставини мають значення не тільки при його оскарженні, але й вПливають на рішення інших судів, які вирішують справу, що має відношення до предмету доказування, який був об’єктом розгляду у суді. Питання преюдиціальних фактів $є$ достатньо дискусійним та підіймалось науковцями у різних процесуальних галузях права України, такими як, О. I. Бережний, Г. Г. Горелікова, В. Д. Шундіков, О. 3. Хотинська, Ю. М. Грошевий, М. О. Тузов, Д. В. Шилін, В. В. Вапнярчук, М. С. Строгович, О. В. Левченко, В. Я. Дорхов та інш. Незважаючи на те, що таке правове явище, як преюдиціальні факти були в центрі уваги багатьох вчених, реформування судової та правової системи викли- кає необхідність перегляду та більш детального аналізу такого важливого процесуального засобу у процесі доказування, як преюдиціальні факти.

Термін «преюдиція» походить від латинського терміну «praejudicium» яке має тлумачення: «вирішення питання наперед; заздалегідь прийняте рішення; обставини, що дозволяють робити висновки про наслідки» [1, c.423].

Поняття «praejudice» містить такі ознаки: законність, обов'язковість ії застосування, достовірність раніше доведених фактів, об'єктивність, зв'язок обставин справи, що розглядається, із судовим рішенням, що набрало законної сили. Виникнення преюдиції пов'язано з діяльністю римських юристів, які подавали преюдиціальні позови (actiones prejudiciales) з метою набуття обов'язкової юридичної сили винесеного судом рішення у певній справі при розгляді судом у майбутньому іншої справи [2, с.22].

У праві Німеччини та Франції преюдиції знайшли остаточне оформлення та законодавче закріплення, що надалі зробило можливим імплементацію цієї правової категорії в законодавчу прак- 
тику більшості країн Європи. Враховуючи те, що Україна тривалий час перебувала у складі інших державних утворень, на формування положень щодо преюдиції вплинуло право Російської імперії та, в подальшому, СРСР. Дореволюційне судочинство запозичило термін «преюдиція» 3 французького процесуального права та іï значення полягало у певних питань, які суд не мав права розглядати, тобто вважався неправомочним. У кримінальному процесі преюдиціальними визнавалися такі правові питання, які задовольняли б таким вимогам: предметом його повинні були бути обставини, що обумовлюють наявність складу злочину; до вирішення цього питання був залучений інший суд, а не суд, що вирішує питання винуватості. Тому, застосування преюдиціі, дозволяло більш кваліфіковано і швидко вирішити справу та уникнути суперечностей між рішеннями різних судів. [3, с. 157].

Великий юридичний словник «преюдицію» або «преюдиціальність» визначає як певну властивість, відповідно до якої всі суди, які розглядають справу, повинні приймати без перевірки і доказів факти, встановлені рішенням або вироком суду, що набули законної сили $[4$, c. 483$]$

В сучасній юридичній літературі «преюдиція» виступає універсальним терміном, який розглядається як правозастосовний факт; як факт, встановлений судом; як висновок, зроблений одним судом і який є обов'язковим для іншого суду; як інтелектуально-вольова діяльність 3 доказування; як властивість окремих правових явищ; як прийом юридичної техніки [2, с. 22].

Головною передумовою виникнення інституту преюдицій у праві стало намагання правотворця усунути потенційну можливість прийняття рішень, які за своїм змістом могли суперечити одне одному, одночасно з тим, щоб мінімізувати вплив попередньо ухвалених рішень на майбутні настільки, наскільки це сприяло б ефективності здійснення правосуддя [5, с. 583 ].
«Преюдиція» має дуже багато спільного 3 такою правовою категорією, як «прецедент», а наявність широкого кола загальних рис, є причиною частого ототожнення визначених категорій. Змістом «прецедента» та «преюдиції є забезпечення стабільності судових рішень та процесуальна економія, яка реалізуються відповідно до правил вирішення певних питань на основі попередніх висновків. «Прецедент» та «преюдиція» $€$ попередніми рішеннями, які констатують результат розв'язуваного питання. Схожими рисами цих правових категорій є також те, що для з'ясування певних обставин використовується раніше винесено рішення. Відмінними рисами є те, що прецедентне рішення $€$ обов`язковим для судів, що розглядають аналогічні справи, а правило преюдиціальності передбачає обов'язковість обставин, встановлених попереднім рішенням суду і що мають значення тільки для справи, яка розглядається, тобто ці факти покладаються в основу наступного рішення без вторинного доказування. Головною відмінністю «преюдиції» від «прецедента» $є$ те, що прецедент утворює правове правило вирішення правового спору, а преюдиція відображає певні юридичні факти та правові висновки, а також є доказовим правилом їх використання. Прецедент стосується у цілому юридичного процесу, а преюдиція реалізується лише у сфері доказування [6, с. 27].

Також важливим є визначення місця преюдиціальних фактів у предметі доказування. Преюдиціально встановлені факти є обставинами, що були встановлені на основі якихось доказів у попередньому провадженні. Ці докази вже пройшли процесуальний порядок доказування: збирання, перевірку й оцінку. Висновки, зроблені на іхній основі, ввійшли до змісту вироку (рішення) і стали преюдиціально встановленими фактами. Тому, ототожнення преюдиціальних фактів 3 доказами $є$ недостатньо вірним, оскільки принципова відмінність між такими категоріями 


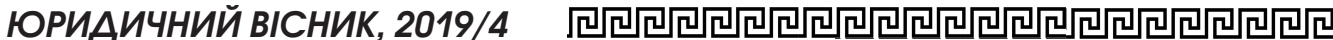

полягає перш за все у тому, що преюдиціі: а) встановлюються в процесі провадження по іншому кримінальному провадженню; б) через це мають процесуальну форму, властиву доказам; в) достовірність ї може бути піддана сумніву в процесі використання під час доказування по іншому кримінальному провадженню (в рамках законної сили вироку чи рішення, тобто поки воно не буде скасоване) [7, с. 15].

Головною причиною ототожнення цих понять можна назвати аналогічний процес оформлення преюдиціальних фактів та доказів у кримінальному провадженні. Для застосування преюдиції у процесі доказування потрібно визначити наявність достатніх підстав, тому слід визначитися із поняттями збирання, перевірки та оцінки доказів. Під збиранням доказів у кримінально-процесуальній науці розуміє діяльність суб єктів, у провадженні яких перебуває справа, спрямована на одержання доказів шляхом проведення передбачених законом дій. Для з'ясування наявності преюдиціальних фактів необхідно витребувати слідчим, прокурором,слідчим суддею, судом необхідних джерел (документів), якими такі факти встановлені. До них належать: вирок або ухвала, постанова, які набрали законної сили. Тому, такий етап процесу доказування, як збирання доказів, характерний і для преюдиціальних фактів [5, с.585].

Наступним етапом процесу доказування є перевірка доказів, тобто аналітична, інтелектуальна діяльність, яка реалізується шляхом аналізу кожного окремого доказу, а також зіставлення доказів між собою. Наявність вже ухваленого процесуального рішення, яке містить важливі встановлені юридичні факти, не є підставою для прийняття нового рішення. Зазначені юридичні факти можуть бути покладені в основу судового рішення тільки у тому випадку, коли в результаті аналітичної, розумової діяльності слідчого, прокурора, суду щодо аналізу змісту попереднього рішення буде доведено, що встановлені ним факти мають дока- зове значення чи входять до предмету доказування у справі [8, с. 4].

Останнім етапом процесу доказування є оцінка доказів. Відповідно до положень ст. 94 КПК України слідчий, прокурор, слідчий суддя, суд оцінюють докази за своїм внутрішнім переконанням, що грунтується на всебічному, повному і об'єктивному розгляді всіх обставин справи в їх сукупності, керуючись законом. Ніякі докази для суду, слідчого судді, прокурора, слідчого не мають наперед встановленої сили. Зазначена норма вказує на необхідність оцінювати і преюдиціальні факти, що $€$ необхідним елементом процесу доказування. Оцінка преюдиціальних фактів провадиться за правилами оцінки доказів, тобто з врахуванням їх належності, допустимості, достовірності, достатності. Належність преюдиціальних фактів вказує на наявність об`єктивного зв `язку між змістом доказів і тими обставинами, що підлягають доказуванню по іншій кримінальній справі, де ці преюдиціальні факти використовуються. Допустимість преюдиціальних фактів - це ознака, яка вказує, що цей факт отримано з належного джерела, уповноваженим на те суб`єктом доказування. Достовірність преюдиціально встановлених фактів пов'язана з достовірністю вироку, рішення чи постанови, що мають преюдиціальну силу. Достатність преюдиціально встановлених фактів визначає рішення суб`єкта доказування з точки зору можливості на їх основі зробити висновок про те, що обставини, які входять до предмета доказування, встановлені в необхідних межах [9, с. 81-84].

Слід звернути увагу не те, що на відміну від норм деяких країн СНД щодо застосування преюдиції, законодавчі акти України не закріплюють заборону оспорювати преюдиціальні факти, якщо вони за внутрішнім переконанням судді встановлені не правильно. Тому, у випадку, якщо буде встановлено, що факт, який був покладений в основу преюдиціального рішення, виявився недостовірним, то попереднє рішення, 
в основу якого він був покладений скасовується, а дія преюдиції припиняється, оскільки вона припускає достовірність самого факту за умови його відповідності вимогам закону [3, с. 4-5].

Правила використання преюдиціальних фактів загалом міститься у нормах матеріального та більшою мірою у нормах процесуального права. В таких процесуальних галузях права, як цивільне, господарське та адміністративне встановлюється, що кожна сторона повинна довести ті обставини, на які вона посилається як на підставу своїх вимог або заперечень. Разом з тим, в Цивільному процесуальному кодексі України, Господарському процесуальному кодексі України та Кодексі адміністративного судочинства України передбачено, що сторони звільняються від доказування певних обставин, однією з яких є преюдиційні обставини. [10, 11, 12].

Правовим підгрунтям застосування принципу «преюдиції» в кримінальному процесуальному законодавстві України є положення статті 90 КПК України, яка визначає, що «преюдиціальне значення для суду, який вирішує питання про допустимість доказів має рішення національного суду або міжнародної судової установи, яке набрало законної сили і ним встановлено порушення прав людини і основоположних свобод, гарантованих Конституцією України і міжнародними договорами, згода на обов'язковість яких надана Верховною Радою України» [13].

Виходячи зі змісту вказаної статті можемо визначити певні характерні риси преюдиціальних фактів:

1. Для суду мають преюдиціальне значення рішення суду, яке прийнято при розгляді кримінальних, цивільних, господарських та адміністративних справ. Крім того, преюдиціальне значення мають рішення міжнародних судових установ (найчастіше це рішення Європейського суду 3 прав людини). Таким чином, можемо вказати на існування галузевої, міжгалузевої та міжнаціональної( міжнародної) преюдиції.
2. Преюдиціальні факти можуть встановлюватися не тільки рішенням, як актом правосуддя - яким закінчується розгляд справи, але й будь-яким іншим судовим рішенням. (Наприклад, ухвалою про закриття провадження у зв'язку з укладанням між сторонами мирової угоди).

3. Судове рішення, в якому містяться преюдиціальні факти, повинно набрати законної сили.

4. Преюдиціальні факти повинні стосуватися тих обставин, які є предметом судового розгляду та тих осіб( або однієї особи), які приймають участь у розгляді справи.

5. Мають важливе правове та процесуальне значення, оскільки скасування рішення суду, встановленні факти якого використовувались у якості преюдиції, може слугувати підставою для перегляду за нововиявленними обставинами.

Отже, термін «преюдиція» виник ще за часів римського права та використовується судами на національному та наднаціональному рівнях, преюдиція має певні характерні риси, завдяки чому, займає своє особливе місце в предметі доказування. Преюдиція - категорія міжгалузева. У нормах цивільного, господарського та адміністративного процесах також містяться норми застосування преюдиціальних фактів, які мають певні відмінності від норм кримінального процесу. Перші звільняють сторони від обов'язку доказування преюдиціальніх фактів, а норми кримінального процесуального законодавства встановлюють, що преюдиціальне значення для суду, який вирішує питання про допустимість доказів має рішення національного суду або міжнародної судової установи, не зазначивши при цьому права та обов'язки сторін щодо таких фактів. Продовжуючи досліджувати преюдиціальні факти потрібно наголосити, що для більшої конкретизації процесу доказування у кримінальному судочинстві на законодавчому рівні є потенційно необхідним закріпити порядок дослідження та аналізу саме преюдиціальних фактів. 


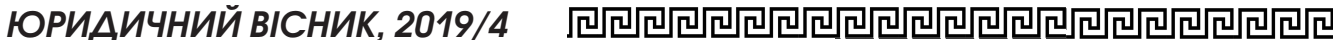

Стаття присвячена дослідженню важливого елементу кримінально-проиесуального доказування преюдиціальним фактам. Термін «преюдиція» у проиесуальній науці означає "вирішення питання наперед; заздалегідь прийняте рішення; обставини, щзо дозволяють робити висновки про наслідки». Преюдииія, як правове явище, закріпилось завдяки римським юристам, які певними правовими діями створювали судові рішення з метою застосування їх $y$ певній майбутній справі. Остаточно преюдиція оформилась у праві Франизї та Німеччині, що у подальшому зробило можливим імплементацію преюдиціi у законодавчу практику европейських держав.

Значення преюдиціі багатогранне, вона може розглядатися як правозастосовний факт; як факт, встановлений судом; як висновок, зроблений одним судом $i$ який $є$ обов'язковим для іншого суду; як інтелектуально-вольова діяльність з доказування; як властивість окремих правових явищ; як прийом юридичної техніки.

Преюдиція має багато спільного з такою правовою категорією, як прецееден, але головною відмінністю ї є те, щьо прецедент стосується у иілому юридичного проиесу, а преюдиція реалізується лише у сфері доказування.

Також в статті було дослідежно місие преюдиціi у предметі доказування. На відміну від доказів, які входять у предмет доказування, преюдииіальні факти вже проходили процесуальний порядок доказування: збирання, перевірку й оцінку, а також зроблені відповідні висновки, які знайшли своє відбиття у судовому рішенні. При застосуванні преюдиціальних фактів у процесі доказування иі факти також будуть проходити етапи збору, дослідження та оиінки, але с певними відмінностями від доказів.

Преюдиція - категорія міжгалузева. В нормах ицвільного, госпо- дарського та адміністративного прочесах також містяться правила застосування преюдиціальних фактів, які мають певні відмінності від норм кримінального процесу. Норми цивільного процесуального, господарського процесуального та адміністративного судочинства звільняють сторони від обов'язку доказування преюдиціальних фактів, а норми кримінального процесуального законодавства встановлюють, щз преюдиціальне значення для суду, який вирішує питання про допустимість доказів має рішення національного суду або міжнародної судової установи. Також в статmі були окреслені характерні риси преюдиції.

Ключові слова: преюдиція, преюдиціальні факти, докази, процес доказування, прецедент

Ustinova-Boychenko G., Chernysh T., Chabanenko U. THE PLACE OF PREJUDICIAL FACTS IN THE PROCESS OF CRIMINAL PROCEDURAL EVIDENCE

The article is devoted to the investigation of an important element of criminal procedural evidence - the prejudicial facts. The term "prejudice" in procedural science means "the solution of the question beforehand; a decision made in advance; circumstances that allow us to draw conclusions about the consequences". Prejudice, as a legal phenomenon, was entrenched by Roman lawyers who, through certain legal actions, created court decisions in order to apply them in a future case. Ultimately, the prejudice of France and Germany took shape, which in the future made it possible to implement the prejudice in the jurisprudence of European states.

The value of a prejudice is multifaceted, it can be considered as a factual fact; as a fact established by the court; as a conclusion made by one court and binding on another court; as intellectual-willful activity 
on proving; as a property of particular legal phenomena; as a technique of legal technique.

Prejudice has a lot in common with a legal category such as precedent, but the main difference is that the precedent applies to the whole legal process, and the prejudice is only realized in the sphere of evidence.

The article also explored the place of prejudice in the subject of proof. Unlike the evidence which is the subject of proof, the prejudicial facts have already passed the procedural order of proving: collection, verification and evaluation, as well as the relevant conclusions, which were reflected in the court decision. When applying the prejudicial facts in the process of proving, these facts will also pass the stages of collection, research and evaluation, but with certain differences from the evidence.

Prejudice is a cross-industry category. The rules of civil, economic and administrative processes also contain rules for the application of prejudicial facts, which have certain differences from the rules of criminal proceedings. Rules of civil procedural, commercial procedural and administrative justice exempt the parties from the obligation to prove the prejudicial facts, and the rules of criminal procedural law stipulate that the prejudicial ruling for the court that decides the admissibility of the evidence is decided by a national court or international court. The article also outlined the characteristic features of prejudice.

Key words: prejudice, prejudicial facts, evidence, proving process, precedent

\section{Література}

1. Двореикий Н. Х. Латинско-русский словарь (около 50000 слов). Москва.:Рус. яз.,1986.1096 c

2. Ляшенко Р.Д. Загальна характеристика та властивості преюдиції як засобу судової аргументації. Часопис Київського університету права. Київ, 2012 / 3. C. 22-25.

3. Проданик I.В. Процесуально-правові засади провадження у справах про взаємопов'язані злочини: дис. ... канд. юрид. наук. Ipniнb. 2017. 230 c.

4. Сухарев А.Я., Крутских В.Е. Большой юридический словарь Москва: ИНФPA-M,2001. 704 c.

5. Бабич Д.С. До питання сутності та меж застосування преюдиціальних фактів у прочесі доказування в кримінальному провадженні. Молодий вчений. № 5 (57). 2018. С. 582-588.

6. Зіменко O.B. Щодо питання преюдиціальності рішень Європейського суду з прав людини. Науковий вісник Ужгород-ського національного університету: Ужгород, 2013. Вип. 22. T. 1. № 1. С. 24-28.

7. Беренний O.I. Значення обставин встановлених у вироку та ухвалі суду про закриття кримінального провадження при вирішенні інших кримінальних проваджень. Журнал східноєвропейського права. 2016. № 33. C. 11-20.

8. Шилін Д.В. Кримінально-проиесуальна преюдиція в процесі дока-зування у кримінальних справах. Часопис Академії адвокатури України. 2010. № 6. С. 01-06.

9. Бережний O.I. Преюдиціальність судових рішень у кримінальних справах: дис. ... канд. юрид. наук. Харків, 2003. $191 \mathrm{c}$.

10. Господарський процесуальний кодекс України: Закон України від 06.09.1991 p. № 1798-ХІ. Дата оновлення 16.11.2019. URL: https: / / zakon.rada.gov. ua/laws/show/ru/1798-12 (Jama звернення 26.11.2019)

11. Цивільний процесуальний кодекс України: Закон України від 18.03.2004 p. № 1618-IV. Дата оновлення 19.10.2019. URL: https: / / zakon.rada.gov.ua / laws / show / ru/1618-125 (дата звернення 26.11.2019)

12. Кодекс адміністративного судочинства України: Закон України від 06.07.2005 р. № 2747-IV. Дата оновлення 20.10.2019. URL: https://zakon.rada.gov. ua/laws/show/ru/2747-15 (Jama звернення 26.11.2019)

13. Кримінальний процесуальний кодекс України. Закон України від 13.04.2012 р. № 4651-VI. Дата оновлення 18.10.2019. URL: https://zakon.rada.gov. иа/laws/main/4651-17 (Дата звернення 26.11.2019). 